OPEN ACCESS

Edited by:

José Laércio Favarin

University of São Paulo, Brazil

Reviewed by:

Manosh Kumar Biswas,

University of Leicester

United Kingdom

Mark Paul Running

University of Louisville, United States

*Correspondence:

Pirjo S. A. Mäkelä

pirjo.makela@helsinki.fi

Specialty section:

This article was submitted to

Crop Biology and Sustainability,

a section of the journal

Frontiers in Sustainable Food Systems

Received: 11 April 2020

Accepted: 11 June 2020

Published: 22 July 2020

Citation:

Lizarazo Cl, Tuulos A, Jokela V and Mäkelä PSA (2020) Sustainable Mixed

Cropping Systems for the Boreal-Nemoral Region.

Front. Sustain. Food Syst. 4:103.

doi: 10.3389/fsufs. 2020.00103

\section{Sustainable Mixed Cropping Systems for the Boreal-Nemoral Region}

\author{
Clara I. Lizarazo ${ }^{1,2}$, Antti Tuulos ${ }^{3}$, Venla Jokela ${ }^{4}$ and Pirjo S. A. Mäkelä ${ }^{1 *}$ \\ ${ }^{1}$ Department of Agricultural Sciences, University of Helsinki, Helsinki, Finland, ${ }^{2}$ Department of Biological and Environmental \\ Science, University of Jyväskylä, Jyväskylä, Finland, ${ }^{3}$ Lantmännen Agro Oy, Vantaa, Finland, ${ }^{4}$ Eurofins Viljavuuspalvelu Oy, \\ Mikkeli, Finland
}

Mixed cropping, including intercropping, is the oldest form of systemized agricultural production and involves the growing of two or more species or cultivars of the same species simultaneously in the same field. However, mixed cropping has been little by little replaced by sole crop systems, especially in developed countries. Some of the advantages of mixed cropping are, for example, resource use efficiency and yield stability, but there are also several challenges, such as weed management and competition. The boreal-nemoral region lies within the region 55 to $70^{\circ} \mathrm{N}$. In this area, for example in Finland, the length of the thermal growing season varies from >105 to over 185 days. Typically, variation between locations and years is marked. However, during the year, there can be a wide range of temperature extremes between -70 and $+30^{\circ} \mathrm{C}$. The majority of cropping systems in this region are usually monocultures, except for forage grass mixtures. The possibility of having several crops in a mixture is very challenging in the region due to the short growing season and extreme cold temperatures, meaning that crop earliness and overwintering capacity are a considerable restriction for year-round mixed cropping. A further restriction is the quality requirements set by the industry. Our review will explore a range of mixed cropping possibilities for the boreal-nemoral region, including different possible combinations of spring, winter, perennial, biennial, catch, and cover crops. The reviewed mixed cropping systems could considerably improve the sustainability and efficiency of crop production.

Keywords: catch crops, cover crops, double cropping, intercropping, nitrogen management, relay cropping

\section{INTRODUCTION}

The oldest form of systemized agricultural production was based on mixed cropping (Plucknett and Smith, 1986). In mixed cropping and intercropping, growing of two or more crop species or cultivars takes place simultaneously in the same field with the aim of improving the resource use efficiency and yield stability, and decreasing losses due to possible pathogen and pest infestation. The main difference is the definite pattern of the crops in intercropping. Relay cropping as well as catch and cover cropping can also be considered as mixed cropping. The specific feature of relay cropping is that the second crop is seeded after the first crop; thus the first crop is harvested well before the second crop, even in the following growing season. In catch cropping, nutrient scavenging crop species are used between the main crops cultivated for yield. Nutrients are fixed into living plant tissues, which minimizes nutrient leaching into the environment (Dabney, 1998; Dinnes et al., 2002). Catch cropping can also improve sustainability, since after incorporation into soil, the nutrients are available for the following main crop (Thorup-Kristensen and Nielsen, 1998). 
Cover cropping is sometimes associated with catch cropping, even though the term refers mainly to a crop covering the soil and thus reducing water and wind erosion (Dabney, 1998).

The advantage of mixed cropping is the higher number of plants per unit area and differences in pest and pathogen resistance as well as stress tolerance of different plant species and cultivars. Due to a dense plant stand, the foliage and roots cover a larger area, thus increasing the radiation (Keating and Carberry, 1993), water (Morris and Garrity, 1993a), and nutrient (Midmore, 1993; Morris and Garrity, 1993b) capture. Mixed cropping could result also in further benefits, such as a lower number of weeds in dense plant stands and a lower number of pests and diseases due to difficulties in detecting hosts and an increased number of natural enemies (Altieri and Liebman, 1986; Trenbath, 1993). However, the plant stand architecture, growth, and dry matter partitioning of species in the mixture can vary due to competition for available resources and species interaction (Silvertown, 1982).

The boreal-nemoral region lies between 55 and $70^{\circ} \mathrm{N}$. The land in this zone experienced heavy glaciation and, as a result, features such as moraines and eskers are common surface features in the region (Metzger et al., 2012). Arable land is limited and agricultural production challenging because of the short length of the growing season (few frost-free days and a small sum of growing degree days or heat units) and the striking changes in day length through the year. In summer, the sun does not set and day length may range from 17 to $19 \mathrm{~h}$ at 55 to $60^{\circ} \mathrm{N}$, respectively [Baldocchi et al., 2000; Tveito et al., 2001; FMI (Finnish Meteorological Institute), 2020]. Conversely, in winter, above the arctic circle the sun does not rise above the horizon, causing a period known as "polar night" when very short days are common and can be as short as $7 \mathrm{~h}$ at $60^{\circ} \mathrm{N}$, for example in Southern Finland [Baldocchi et al., 2000; Anonymous, 2020; FMI (Finnish Meteorological Institute), 2020]. Large variations in day length mean that the region also experiences large variations in temperature range during the year, and thus crop production is restricted to the southern edge of the region, while grasslands are cultivated further north (Heikkilä and Seppä, 2003; Metzger et al., 2012).

For the present review, we will define the boreal-nemoral region in Europe as including Denmark, Estonia, Finland, Latvia, Lithuania, Norway, and Sweden, all countries that lie above $55^{\circ} \mathrm{N}$. Strict or constant limits for the southern fringe of the boreal-nemoral region are elusive; for example, in some reports the southern edge of Norway and the whole of Denmark are outside the nemoral zone (Metzger et al., 2012), while in others they are part of the boreal-nemoral region (Hagen et al., 2013). In addition to cases from the above countries, we also include examples from Canada, where the provinces of Alberta, Manitoba, Nova Scotia, and Saskatchewan are all above $49^{\circ} \mathrm{N}$ and where there are valuable examples of mixed cropping systems that, thanks to their similar climate and land features, could be implemented in the boreal-nemoral region in Europe.

In the boreal-nemoral region, most common mixtures include legumes because of their symbiosis with atmospheric nitrogen $\left(\mathrm{N}_{2}\right)$ fixing Rhizobium species, for which reason the requirement for fertilizer application is either decreased or excluded (e.g.,
Andersen et al., 2005). In mixtures, legumes are mainly grown with forage grasses but in some cases also with cereals and rapeseed. Typical examples are oat (Avena sativa L.)-vetches (Lauk and Lauk, 2009), ley mixtures, and small grain cerealspea (Pisum sativum L.) (Harper, 1983) as well as leys undersown with small grain cereal (Känkänen et al., 2001; Känkänen and Eriksson, 2007).

In this review, we will discuss different mixed cropping possibilities, including also intercropping and relay, catch, and cover cropping, for the boreal-nemoral region. The main emphasis is on ways to improve the sustainability and efficiency of crop production.

\section{MIXED CROPPING}

In mixed cropping, two to several different plant species or cultivars are grown at the same time in a plant stand. Therefore, the individual plants have complex interactions with each other, which might result in an altered assimilate partitioning and thus growth and senescence both in above- and belowground plant parts (Silvertown, 1982). Furthermore, competition for resources also changes throughout the growing season. Early in the season, plants compete mainly for water and nutrients, whereas competition for light takes over later in the season as the foliage expands. At the end of the season, the original plant stand density affects the severity of competition and thus the final number of remaining plant individuals. Environmental conditions, such as temperature and precipitation, may be more favorable to one over another species. Finally, the properties of species in the mixture and their ability to utilize available resources will determine the dominance. For example, deeprooted and tap-rooted species restrict the growth of shallowrooted ones due to better access to deep soil moisture and nutrients (Harper, 1983; Vandermeer, 1989). A further challenge is caused by weeds (Vandermeer, 1981).

When planning mixed plant stands, it is important to take into account the different characteristics and features of the component species of the mixture and the mixture itself, especially the growth habit to avoid competition (Vandermeer, 1989); for example, root systems of different species often avoid each other (Silvertown, 1982), the nutritional requirement and timing of nutrients as well as other resources differ between species, not to mention the synthesis and tolerance of allelochemicals (Zimdahl, 2004). Solutions to alleviate the competition include adjusted seeding times and densities of the component species to maximize the plant stand productivity (Davies et al., 1986). Growth advantage for inferior species of the mixture can be achieved for example by seeding the dominant species later than the other species (Andersen et al., 2007).

Properly planned mixed cropping can improve the sustainability, productivity, as well as yield (Vandermeer, 1989; Fukai and Trenbath, 1993). Mixed stands remove higher amounts of nutrients with yield in comparison with sole crops, resulting in higher nutrient use efficiency (Midmore, 1993; Morris and Garrity, 1993a). This should be taken into account especially in environments with limited nutrient availability (Midmore, 1993). Radiation use efficiency is usually also 
improved in mixed crops due to increased leaf area index (Keating and Carberry, 1993), restricting also the existence of weeds. However, in a dense canopy, shading increases and can result in a situation where assimilation is exceeded by respiration (Black, 1963). Bigger leaf cover also leads to improved water use efficiency because of lower evaporation and soil temperature (Morris and Garrity, 1993b). Even though mixed crops usually consist of species reaching maturity at the same time, most yield advantage is obtained from crops reaching maturity at different times. As an extreme, in relay cropping, the second component of the two-crop mixture is seeded markedly later than the first one, although well before harvest of the first crop (Francis, 1986). This allows the later seeded crop to utilize the resources without marked competition (Fukai and Trenbath, 1993) as well as consecutive growing of two crops in a limited growing season (Tuulos et al., 2015b). Examples of relay cropping in the boreal-nemoral region include mixed spring and winter crops, such as oilseeds and cereals, which can potentially be used for forage in the vegetative stage (Davidson et al., 1990; Tuulos et al., 2015a) and harvested for seed yield in the later stage (Tuulos et al., 2015a).

\section{Perennial Forage Mixtures}

The best-known and most utilized crop mixtures around the world are most likely forage. Also in the boreal-nemoral region, forage is commonly grown in perennial mixtures, either in binary or more complex mixtures, typically including both grasses and legumes. For example, in Finland most of the forage produced for cattle, both for silage and grazing, consists at least of a few grass species and one forage legume species. The most commonly used species include timothy (Phleum pretense L.), meadow fescue (Festuca pratensis Huds.), tall fescue (Festuca arundinacea Schreb.), perennial ryegrass (Lolium perenne L.), $\times$ Festulolium, red clover (Trifolium pratense L.), and white clover (Trifolium repens L.). In pastures, Kentucky bluegrass (Poa pratensis L.) is also commonly used. The same species combinations are used at the same latitudes also, for example, in Sweden, Norway, and Canada, with some variation depending on the local climatic factors. Winter tolerance is one of the most important features when selecting perennial crops for forage production at high latitudes; thus species and cultivars must be carefully selected. However, recently more winter tolerant cultivars, for example for perennial ryegrass, have been introduced, and the cultivation area has expanded to more harsh winter climates in the continental regions (Helgadóttir et al., 2018a). Alfalfa (Medicago sativa L.) is not yet cultivated extensively, but there might be more possibility for this in the future due to the warming climate and breeding of new cultivars (Annicchiarico et al., 2019).

A higher yield in perennial forage mixtures is mainly due to higher biodiversity and different functional plant groups. In perennial forage mixtures, plants are typically divided into three groups: grasses, $\mathrm{N}$ fixing legumes, and other herbaceous species. Although species belonging to different functional groups are supposed to be more complementary, even mixtures containing only two different grass species have been shown to produce higher dry matter yield than sole one species stands (van Ruijven and Berendse, 2003; Ergon et al., 2016; Helgadóttir et al., 2018b). Moreover, a stable yield increase was seen when more grass species were added to a mixture of $2,4,6$, or 8 species (van Ruijven and Berendse, 2003). Although van Ruijven and Berendse (2003) included also grass species with nonagronomic importance in their study, valuable information on the biodiversity effect of mixtures containing only grasses was gained. However, in a study where legumes, red and white clover, and alfalfa were grown in sole stands and mixtures without grasses, the over-yielding effect was not observed (Dhamala et al., 2017).

Different physiological characteristics and growth habits of grasses benefit biodiversity; for example, timothy has shallower (Bertrand et al., 2008) and Festuca deeper root systems (Humphreys et al., 2013; Mäkinen et al., 2018) and thus resources can be allocated more evenly among species. In the spring, timothy has quite fast growth but the regrowth ability in the following cuts is slower and dry matter yield lower (Seppänen et al., 2010; Virkajärvi et al., 2012) compared with perennial ryegrass and Festuca, which can produce higher dry matter yields in the following cuts (Frame and Laidlaw, 2011). These differences between species benefit forage growth and thus enable larger yields.

The main advantage of using legumes in the perennial grass mixtures is the improvement of $\mathrm{N}$ supply through biological $\mathrm{N}$ fixation for non-legume species (Dahlin and Stenberg, 2010). Legumes are able to fixate the atmospheric $\mathrm{N}$ into the soil, and grasses and other species growing in the same mixture can use $\mathrm{N}$ for their growth. Plant diversity in the perennial mixtures increases the $\mathrm{N}_{2}$ fixation mainly as a result of the non-legume species competition for $\mathrm{N}$ from soil (Carlsson and Huss-Danell, 2003; Rasmussen et al., 2012). For example, Li et al. (2019) showed that an unfertilized timothy-red clover mixture had higher dry matter yield than $\mathrm{N}$ fertilized sole stands in Finland because through biological $\mathrm{N}$ fixation plants were able to utilize resources more efficiently. Dhamala et al. (2017) concluded that perennial mixtures need to have non-legume species to maximally benefit from the $\mathrm{N}_{2}$ fixation. However, under northern growing conditions it should be taken into account that symbiotic $\mathrm{N}_{2}$ fixation is very dependent on temperature and is possible only during the most favorable summer months.

Grass-legume mixed swards produce higher dry matter yields in comparison with grass swards, possibly due to biological $\mathrm{N}$ fixation. For example, dry matter yield was $33-65 \%$ higher in grass-clover mixtures compared with sole stands of perennial ryegrass, cocksfoot (Dactylis glomerata L.), and white or red clover canopies in a 3-year field trial in southern Sweden (Frankow-Lindberg et al., 2009) and $21-32 \%$ higher in grassclover mixtures compared with sole stands of timothy, Kentucky bluegrass, and white or red clover canopies in a 3-year field trial in northern Europe and Canada (Sturludóttir et al., 2013). In Iceland, Helgadóttir et al. (2018b) reported as high as $71 \%$ yield advantage in mixtures compared with sole stands of timothy, meadow fescue, and red and white clover across a 5-year field trial. Large differences between separate studies are partly explained by the differences in the experimental locations as well as the species used and their ability to use resources efficiently. Research conducted at 31 different sites, including Finland, 
Sweden, Norway, and Iceland, reported that mixtures containing both grasses (timothy, perennial ryegrass, cocksfoot, Kentucky bluegrass) and legumes (red and white clover, alfalfa) produce on average $32 \%$ higher yield compared with monocultures (Finn et al., 2013). Interestingly, adding alfalfa to the mixture increased dry matter yield only by $7 \%$ (Finn et al., 2013), 8\% (Bélanger et al., 2014), and 12\% (Thompson, 2013) over the best monoculture.

Including several species in the perennial forage production generally also improves feed security. In the boreal-nemoral growing conditions, winter hardiness is still one of the key issues for forage production, and some species and cultivars are better adapted. Generally, grasses have better winter hardiness than legumes; thus the former must be included in the mixtures.

Legumes in perennial swards typically improve the nutritional quality of the yield. According to Mela (2003), grass and red clover mixtures produce higher protein and crude fiber content compared with sole grass swards in Finland. Sturludóttir et al. (2013) reported better digestibility and high crude protein content in grass-clover mixed swards compared with grass monocultures in northern Europe and Canada. Adding alfalfa to a grass mixture improved neutral detergent fiber (NDF) concentration and digestibility in a Canadian study (Bélanger et al., 2014). Moreover, adding red clover to a mixture has shown to increase the milk production and quality in dairy cows (Heikkilä et al., 1992). It can be concluded that adding legumes to mixtures has a positive effect on the nutritive value of the yield without a negative effect on the dry matter yield.

Mixtures also reduce the invasion of weeds and other unwanted species. In sole stands of grasses and legumes even $10-60 \%$ of the dry matter yield can be weeds, whereas in mixtures the proportion can be $<2-5 \%$ of the dry matter yield as shown in several studies conducted in the boreal-nemoral region (Frankow-Lindberg et al., 2009; Finn et al., 2013; Sturludóttir et al., 2013; Bélanger et al., 2014; Helgadóttir et al., 2018b). Mixtures are able to use resources more efficiently compared with sole stands, and therefore weeds are not able to invade the plant stand. Furthermore, mixtures produce higher dry matter yields which partly suppress weeds and other unwanted species.

\section{Perennial Forage Mixtures With Forage Herbs}

Recently, even more exotic species, i.e., non-leguminous dicotyledon forage herbs (forbs), such as ribwort plantain (Plantago lanceolata L.), chicory (Cichorium intybus L.), and salad burnet (Sanguisorba minor L.) have been tested for perennial forage mixtures. Reasons to introduce these species include the potential to increase plant diversity, competitiveness, and tolerance to different weather conditions (Eriksen et al., 2012; Pirhofer-Walzl et al., 2012), and improvement in the nutritional quality (Pirhofer-Walzl et al., 2011).

In several Danish experiments, forage herbs, including ribwort plantain and chicory, have been studied to reveal the potential for forage production. Dhamala et al. (2018) showed that forbs can be used in perennial mixtures without a negative effect on the yield or amount of biological $\mathrm{N}_{2}$ fixation, but the amount of forbs in the mixture needs to be low. Typically, forbs are rich in minerals and thus could possibly serve as balancing supplements in mixtures. Plantain and chicory had higher concentrations of some macro- and micronutrients, such as phosphorus, magnesium, potassium, boron, sulfur, and zinc, compared with grasses and legumes (Pirhofer-Walzl et al., 2011). Using a multispecies grass-forage-forb mixture as the main feed source for milking cows reduced the need for artificial mineral supplements and simultaneously increased some ecosystem services, for example, foraging sites for pollinators (PirhoferWalzl et al., 2011). In multispecies mixtures, grasses took a higher amount of $\mathrm{N}$ fixed by clover, whereas forbs used soil $\mathrm{N}$ for growth (Dhamala et al., 2017). It seems that forbs could balance perennial forage mixtures in a sustainable way and use resources differently compared with grasses and legumes.

Forbs are not commonly used in the boreal-nemoral region in grasslands and thus not many extensive field trials with forbs have been conducted. In Finnish advisory groups, chicory has been tested in multispecies mixtures for silage production. Preliminary results have indicated that chicory has potential also in Finnish growing conditions, especially in fields facing drought problems and for plots intended for fast rotation grazing (Proagria, 2017).

\section{Mixed Cropping by Combining Spring Crops}

Traditionally the most typical spring crop combinations in the boreal-nemoral region have been the grain legume-cereal mixtures grown for whole crop forage, mainly pea (Pisum sativum L.) mixed with oat (Avena sativa L.), barley (Hordeum vulgare L.), and wheat (Triticum aestivum L. em. Thell.). Due to their usage as forage, the majority of studies have focused on the nutritive value and ensiling of mixed spring crops. In grain legume-cereal mixed crops the forage quality is higher in comparison with sole cereal forage. Grain legume-cereal mixed crop forage has higher crude protein content, higher protein yield, and higher relative feed value, and it can provide alternatives to more traditional forage (Strydhorst et al., 2008). However, less focus has been paid to environmental, ecological, and physiological traits of the grain legume-cereal, cereal species, and cereal cultivar mixtures. The major obstacle for species and cultivar mixtures for grain has most likely been the problems in marketing the yield, since the industry has so far been interested in sole crop grains. Separating the seeds of different cultivars and species for industrial processes is time-consuming and expensive. A further challenge has been harvesting mixed grain crops, since the components have to reach maturity at the same time. However, in low-input cropping systems there can be both ecological and economic advantages of cultivating spring crop mixtures not only in tropical regions but also in the boreal-nemoral region.

Due to its suitability to boreal-nemoral growing conditions and the long tradition of including it in mixed crops, pea has been the most studied grain legume as a component crop. Pea-barley mixtures have been extensively studied for example in Denmark, and pea in combination with other spring cereals, for example triticale ( $\times$ Triticosecale Wittm. ex A. Camus), wheat, and oat in Estonia, Finland, and Lithuania. Other grain legumes studied for mixed crops with cereals include narrow-leafed lupin (Lupinus angustifolius L.), faba bean (Vicia faba L.), and oilseed rape 
(Brassica napus L. ssp. oleifera (Moench.) Metzg.). In Denmark and Canada, studies have also involved tri-crop combinations, i.e., oilseed rape and pea with either wheat or barley. A less traditional faba bean-maize (Zea mays L.) mixture for forage production has gained interest in Sweden (Stoltz et al., 2018).

In general, the pea-cereal mixtures (Table 1) have been higher yielding than the sole crops, especially when grown without $\mathrm{N}$ fertilizer on soils with low fertility (Ghaley et al., 2005; Lauk and Lauk, 2008). According to Knudsen et al. (2004), the dominant species in grain legume-barley mixtures were legumes on sandy loam and barley on sandy soil. In Estonia, pea-cereal mixtures with oat, wheat, and barley grown on sandyclayey soil without fertilizers produced higher grain yield and protein yield than sole crops. The highest yielding combination was a pea-oat mixture, in which case the yield of oat was higher than the yield of the sole oat crop, especially when the seeding rate of pea ranged from 20 to 80 seeds $\mathrm{m}^{-2}$, when the optimum for pea as a sole crop is from 100 to 120 seeds $\mathrm{m}^{-2}$ (Lauk and Lauk, 2008). Increased plant stand density favors pea over barley, which is seen in decreased yield and yield stability of the barley component and increased yield stability of the pea component (Jensen, 1996). Similarly, the lupin component is suppressed in a mixed crop with barley when the plant stand density increases (HauggaardNielsen et al., 2008). Furthermore, competition by pea in mixed crops decreased both the grain size and the protein content of cereals (Lauk and Lauk, 2008), indicating that the increase in protein yield of the mixed crop was due to the pea component. In Denmark, a pea-wheat mixture grown on sandy loam soil was most productive without fertilizers (Ghaley et al., 2005). Increasing the rate of $\mathrm{N}$ fertilizer gave a competitive advantage to wheat, thus suppressing the growth of pea, although without a decrease in intercrop grain yield. Without $\mathrm{N}$ fertilizer, pea as a component of a pea-wheat mixed crop fixed more $\mathrm{N}$ than a sole crop (Ghaley et al., 2005), although faba bean and lupin are even more efficient in $\mathrm{N}$ fixation as component crops in grain legume-cereal mixtures (Hauggaard-Nielsen et al., 2008).

In pea-barley mixed crops, barley has proven to be a strong competitor for $\mathrm{N}$ and thus seems to have a negative effect on N fixation when dominant (Jensen, 1996; HauggaardNielsen and Jensen, 2001). Hauggaard-Nielsen et al. (2001) observed that $\mathrm{N}$ fixation of pea decreased from $120 \mathrm{~kg} \mathrm{ha}^{-1}$ in sole pea crops to $30 \mathrm{~kg} \mathrm{ha}^{-1}$ in a pea-barley mixed crop. According to Jensen (1996), N fixation decreases with increased $\mathrm{N}$ fertilization, because it gives further competitive advantage to barley over the grain legume. Barley seedling emergence and the growth of its root system in time and space are faster than those of pea, thus allowing barley to explore a larger soil volume earlier in the growing season as well as shade the pea foliage (Hauggaard-Nielsen et al., 2006). However, the competition between the grain legume and the cereal depends on the cultivar traits of the component crops, such as the emergence and growth rates, determinate/indeterminate growth type, height, leaf area, and tiller formation. For example, Hauggaard-Nielsen et al. (2001) reported that unlike determinate pea, indeterminate pea in the mixture decreased both the $\mathrm{N}$ uptake and the grain yield of barley. For a list of the traits of an optimal pea cultivar for mixed crops with cereals, see the review by Hauggaard-Nielsen et al., 2003.

When pea-barley and pea-oilseed rape mixtures were compared with their sole crop counterparts in Saskatchewan, Canada, it was found that both oilseed rape and barley grown in a mixture together with pea yielded better than sole crops without $\mathrm{N}$ fertilizer, resulting in land equivalent ratio values up to 1.56 (Malhi, 2012). However, the yield of individual components in a mixture decreased. In mixtures, the protein content of both barley and oilseed rape was higher, but the oil content of oilseed rape was lower than in the sole crops (Malhi, 2012). Similarly, in Finland, a mixed crop of faba bean and oat produced higher grain yield than their sole components but only under poor growing conditions. This was related to better growth of faba bean in a mixture with wheat, mainly resulting in heavier grains of faba bean but also an increased number of panicles of oat (Helenius and Ronni, 1989). However, oat benefited more than faba bean from the mixture (Helenius, 1990).

Helenius and Ronni (1989) observed in Finland that mixed cropping of faba bean and oat increased the number of bird cherry-oat aphids (Rhopalosiphum padi L.) on the oat component but decreased the number of black bean aphids (Aphis fabae Scopoli) and weevils (Sitona spp.) on the faba bean component. In a faba bean-maize mixture, the severity of leaf spots on the faba bean decreased by up to $57 \%$ in comparison with a sole crop in Sweden (Stoltz et al., 2018) and by $20-40 \%$ in comparison with a grain legume-cereal mixed crop in Denmark (Hauggaard-Nielsen et al., 2008). Stoltz et al. (2018) concluded that the decrease could be related to a higher copper content of the plants in mixed crops. Mixed cropping increased the macro- and micronutrient uptake and thus nutrient use efficiency of component crops. Interestingly, in Finland, only the macronutrient content of oat increased in the faba beanoat mixed crop (Helenius, 1990). A further advantage of the mixed crops was observed in Lithuania in the rate of weed infestation, which was up to 1.6-fold less in pea-cereal mixtures in comparison with a sole pea crop (Deveikyte et al., 2009). Similar marked decreases in weed infestation of grain legumecereal mixed crops in comparison with sole grain legume crops have been reported also in other studies conducted within the boreal-nemoral region (e.g., Hauggaard-Nielsen et al., 2001, 2006, 2008; Sarunaite et al., 2010). In the majority of cases, mixed cropping tends to increase the reliability and stability of the grain legume component. Therefore, farmer interest toward the mixtures especially in the low $\mathrm{N}$ input systems, such as organic systems, and protein production is expected to increase as knowledge increases.

Adding the third crop component into the mixture peaoilseed rape-wheat further increased the grain yield of the mixture in Canada (Szumigalski and Van Acker, 2006). Szumigalski and Van Acker (2006) explained the increased grain yield through $\mathrm{N}$ use complementarity of the three crops as well as increased light interception and spatial partitioning of water extraction between the crops (Szumigalski and Van Acker, 2008). Further advantages of three component mixtures 
TABLE 1 | Land equivalent ratio (LER) values of different mixed spring crops grown in the boreal-nemoral region.

\begin{tabular}{|c|c|c|c|}
\hline Harvest & Component crops & LER value & References \\
\hline Biomass & Pea-barley & 1.02 & $\begin{array}{l}\text { Hauggaard-Nielsen } \\
\text { et al., } 2006\end{array}$ \\
\hline Biomass & Pea-barley & $\begin{array}{l}1.17 \\
1.05\left(50 \mathrm{~N} \mathrm{~kg} \mathrm{ha}^{-1}\right)\end{array}$ & $\begin{array}{l}\text { Hauggaard-Nielsen and } \\
\text { Jensen, } 2001\end{array}$ \\
\hline Grain yield & Pea-barley & $\begin{array}{l}1.18 \\
1.07\left(50 \mathrm{~N} \mathrm{~kg} \mathrm{ha}^{-1}\right)\end{array}$ & $\begin{array}{l}\text { Hauggaard-Nielsen and } \\
\text { Jensen, } 2001\end{array}$ \\
\hline Grain yield & Pea-barley & $\begin{array}{l}1.54 \\
1.29\left(40 \mathrm{~N} \mathrm{~kg} \mathrm{ha}^{-1}\right)\end{array}$ & Malhi, 2012 \\
\hline Grain yield & Barley cultivars & $\begin{array}{l}0.99\left(50 \mathrm{~N} \mathrm{~kg} \mathrm{ha}^{-1}\right) \\
0.99\left(100 \mathrm{Ng} \mathrm{ha}^{-1}\right)\end{array}$ & Jokinen, 1991b \\
\hline Grain yield & Oilseed rape-wheat & 1.00 (N unknown) & Hummel et al., 2009 \\
\hline Grain yield & $\begin{array}{l}\text { Pea-wheat } \\
\text { Pea-oilseed rape } \\
\text { Wheat-oilseed rape } \\
\text { Pea-wheat-oilseed rape }\end{array}$ & $\begin{array}{l}0.99 \\
1.20 \\
1.09 \\
1.14\end{array}$ & $\begin{array}{l}\text { Szumigalski and Van } \\
\text { Acker, } 2005\end{array}$ \\
\hline Biomass & $\begin{array}{l}\text { Pea-barley } \\
\text { Pea-oilseed rape } \\
\text { Oilseed rape-barley } \\
\text { Pea-barley-oilseed rape }\end{array}$ & $\begin{array}{l}1.15\left(5 \mathrm{~N} \mathrm{~kg} \mathrm{ha}^{-1}\right) \\
1.00\left(40 \mathrm{~N} \mathrm{~kg} \mathrm{ha}^{-1}\right) \\
1.32\left(5 \mathrm{Ng} \mathrm{ha}^{-1}\right) \\
1.16\left(40 \mathrm{~N} \mathrm{~kg} \mathrm{ha}^{-1}\right) \\
1.33\left(5 \mathrm{Ng} \mathrm{ha}^{-1}\right) \\
0.98\left(40 \mathrm{~N} \mathrm{~kg} \mathrm{ha}^{-1}\right) \\
1.26\left(5 \mathrm{Ng} \mathrm{ha}^{-1}\right) \\
1.16\left(40 \mathrm{Ng} \mathrm{ha}^{-1}\right)\end{array}$ & Andersen et al., 2005 \\
\hline
\end{tabular}

All crops received $0 \mathrm{~N} \mathrm{~kg} \mathrm{ha}^{-1}$ fertilizer unless otherwise stated.

were achieved in the competitive ability and yield stability of the mixture. A three-crop mixture of pea, oilseed, and wheat increased the weed suppression ability of the plant stand in comparison with sole crop and two-crop mixtures. The weed biomass as well as relative weed density and biomass were lowest in the three-crop mixture. Competition ability and the ability to withstand competition were nearly the same in the threecrop mixture and wheat and wheat-oilseed rape mixtures. Even though a pea-oilseed rape mixture produced the highest grain yield, adding the third component crop, wheat, into the mixture increased the grain yield stability over years and locations (Szumigalski and Van Acker, 2005). However, in Denmark, when only the biomass production was evaluated in a similar threecrop mixture, the results indicated that two-crop mixtures had higher productivity in comparison with three-crop mixtures, both mixtures out yielding the sole crops. This was related to suppressed barley growth in three-crop mixtures (Andersen et al., 2007). Andersen et al. (2007) concluded that the most marked effect on productivity is between the sole crop and mixed crop systems, whereas adding further components into a mixture does not considerably affect the productivity of the mixture.

Less attention gained are spring cereal cultivar and species as well as oilseed rape-cereal (Hummel et al., 2009), cereal-flax (Linum usitatissimum L.), and cereal-oriental mustard (Brassica juncea L.) mixtures (Pridham and Entz, 2008). The oilseed rapewheat mixture produced similar grain yields to sole crops, and the oil content of the oilseed rape as well as protein content of wheat increased in mixed crops. However, the leaf disease infestation of wheat increased in mixed crops, most likely due to higher humidity in the plant stand with increased foliage brought along by oilseed rape. Furthermore, flea beetle damage was similar in sole crops and mixed crops (Hummel et al., 2009). Although the wheat flag leaf disease level decreased in a wheat-flax mixture, flax outcompeted wheat, resulting in poor grain yield. A wheatoriental mustard mixture was in general higher yielding than the sole crops, but suffered from flea beetle (Phyllotreta cruciferae Goeze), disease, and weed infestations (Pridham and Entz, 2008).

In Finnish and Canadian experiments conducted with cereal cultivar and species mixtures, and sole crops, only limited 
advantages have been observed in cereal cultivar and species mixtures over sole crops. According to Jokinen (1991a,b) growing barley in two to four cultivar mixtures did not increase the grain yield and the yield stability of the plant stand, contrary to the common argument of increased stability from diversity of genotypes [reviewed in Vandermeer (1989)]. Similar results were obtained by Pridham and Entz (2008) when wheat was grown in a mixture with oat, barley, and spring rye (Secale cereale L.). However, in Finland, a barley-oat mixture produced slightly higher total yield in comparison with sole crops (Jokinen, 1991d). In the mixed plant stands, species competition affected mostly the number of panicles, heads, and grains. However, the weight and protein content of the grains was not affected (Jokinen, 1991d). As part of a mixture, barley was more competitive than oat, especially with an increased rate of $\mathrm{N}$ fertilization. This could be explained by the ability of barley to respond through variation in yield components in response to changes in plant stand density and the availability of nutrients (Jokinen, 1991c). However, the cereal species mixtures could decrease the yield losses due to diseases. In spring, wheat cultivar mixtures based on glume blotch (Septoria nodorum Berk.) susceptible and resistant cultivars, Karjalainen (1986) observed that in the mixed crops the amount of disease was always less in comparison with sole crops regardless of whether the disease level was low or high. Although under the low disease level the advantage of a mixed crop was clear, under the high disease level only the progress of the disease was slowed down (Karjalainen, 1986). Based on these observations, cereal species and cultivar mixtures could be ecological options, since there is a possibility of minimizing the need for pesticides. The challenge so far with cereal species and cultivar mixtures has been marketing the yield for industrial purposes.

\section{Mixed Cropping by Combining Spring and Winter Crops}

The majority of investigations have focused so far on mixed spring crops in the boreal-nemoral region. A less well-known and less investigated type of mixed crop is the combination of a seedproducing winter crop established as a relay crop with a spring cereal. A few potential crop combinations have been studied and to some extent used in practical farming at least in Finland.

Tuulos et al. (2015a,b) studied the establishment of winter turnip rape (Brassica rapa L. ssp. oleifera (DC.) Metzg.) by undersowing with various spring cereals in Finland. Winter turnip rape is better suited to the cold temperatures and lowinput cropping systems of the boreal-nemoral region than winter oilseed rape (Mäkelä et al., 2011). However, winter turnip rape needs to be sown by the end of July for successful overwintering under Finnish conditions, which is early compared with winter oilseed rape. Therefore, in a winter turnip rape sole crop during the early part of the growing season, the field needs to be an earlyharvested grass-ley, fallow, or set-aside land, as none of the other crops cultivated in Finland generally reaches maturity by mid to late July. Establishing winter turnip rape simultaneously with a spring cereal allows harvesting of the cereal seed yield during the first growing season of the plant stand, while winter turnip rape remains in a vegetative growth stage (Tuulos et al., 2015b). Winter turnip rape enters the reproductive growth stage during the second growing season, after overwintering and vernalization (Tuulos et al., 2015a).

Undersowing winter turnip rape with spring cereals was attempted in the 1950s (Valle, 1951), but the method remained marginal. The main reason for abandoning the method after the early 1950s was the difficulty in cereal harvesting, especially in the case of the cereal stand lodging over the winter turnip rape stand, suppressing its growth. However, there are currently five different active ingredients and over 20 commercial plant growth regulator products available for the prevention of cereal lodging in Finland [TUKES (Finnish Safety and Chemicals Agency), 2020]. The use of plant growth regulators for cereals would decrease the risk of lodging and thus the risks related to cereal harvest and suppressed turnip rape growth.

In the work of Tuulos et al. (2015a), winter turnip rape was sown either with normal seeding density (150 viable seeds $\mathrm{m}^{-2}$ ) or double seeding density (300 viable seeds $\mathrm{m}^{-2}$ ) in Finland. The seeding densities of cereals were normal or reduced by $20 \%$, respectively. The seeding time of winter turnip rape was either simultaneous with the spring cereal in May (mixed and sole stands) or as sole stands at the end of July. Two separate passes were required with a seeder; the seeding rows were parallel to each other. The establishment cost could be reduced if the crops were sown simultaneously. All tested spring cereals (oat, wheat, two-row barley, six-row barley) were suitable as nurse crops for undersown winter turnip rape (Tuulos et al., 2015b). Undersown winter turnip rape did not decrease cereal yields, even though wheat yield was affected by year. A cereal yield increase due to undersown winter turnip rape was observed with six-row barley and oat in some years. An explanation for the phenomenon was not identified by Tuulos et al. (2015b), but a similar increase in barley yield with undersown field cress (Lepidium campestre (L.) W.T. Aiton), a biennial crucifer, was observed by Merker et al. (2010) under Swedish conditions. Cereal yields tended to be slightly lower in the reduced cereal seeding density plant stands (Tuulos et al., 2015b), but with winter turnip rape, differences between different seeding methods and seeding densities were not evident (Tuulos et al., 2015a). Differences in winter turnip rape yields between years were attributed to overwintering conditions. In overwintering conditions similar to the long-term average in Finland, winter turnip rapeseed yields ranged from 1,800 to $2,300 \mathrm{~kg} \mathrm{ha}^{-1}$ in stands established by undersowing or as the sole crop (Tuulos et al., 2015a).

Undersowing winter oilseed rape with a spring cereal does not necessarily create advantage in crop establishment, since winter oilseed rape can be sown later than winter turnip rape and after the harvest of an early spring cereal or winter cereal. Nordestgaard (1982), however, investigated the undersowing of winter oilseed rape with spring barley under Danish conditions. Nordestgaard (1982) concluded that the overwintering percentage of winter oilseed rape was decreased when the crop was established by undersowing, mostly due to hypocotyls growing too tall during the first growing period and thus being later in the winter exposed to freezing temperatures above the snow cover. Additionally, some of the winter oilseed 
rape hypocotyls were already cut off during the barley harvest, thus destroying the plants (Nordestgaard, 1982).

Kakko et al. (1997) studied in Finland the possibility of establishing winter rye and winter wheat by undersowing with spring barley in an attempt to decrease the need for soil tillage in cereal production. An additional benefit of the method was the avoidance of winter cereal seeding under poor seeding conditions with rains and excess soil moisture typical of late August and early September. Winter cereal seeding was done in a separate pass with a seeder before the emergence of spring barley. In order to minimize interrow competition and to establish as evenly distributed a mixed stand as possible, the second pass with seeder was performed crosswise to the direction of the first pass. Interestingly, winter rye (cv Ponsi) was not suitable for undersowing due to a large proportion of it entering the generative growth stage already during the first growing period. In contrast, winter wheat remained fully in the vegetative stage during the first growing period, while barley entered generative growth and produced harvestable seed (Kakko et al., 1997).

Overwintering performance of winter wheat was good, without winter damage observed. Growth of undersown winter wheat after overwintering was $\sim 9$ days ahead of autumn-sown, sole crop winter wheat. However, both barley and winter wheat yield in the undersowing method was decreased compared with normally established sole crops, although not drastically. The yield of undersown winter wheat was on average $450 \mathrm{~kg} \mathrm{ha}^{-1}$ smaller in comparison with the yield of autumn-sown sole crop. The yield decrease in barley in mixed cropping was $320-520 \mathrm{~kg}$ $\mathrm{ha}^{-1}$ in comparison with the sole crop. Additionally, the barley yield of undersown plots fulfilled the quality limitations set for malting due to decreased protein content, which was 0.5$1.0 \%$ points lower in the mixed crop compared with the sole crop barley (Kakko et al., 1997). The decrease in barley yield seemed to be dependent on the cultivar, as yield reduction was on average only $100 \mathrm{~kg} \mathrm{ha}^{-1}$ with cr Kymppi, a late tworow cultivar, but $900 \mathrm{~kg} \mathrm{ha}^{-1}$ with $\mathrm{cv}$ Arve, an early six-row cultivar. Despite the lower tillage cost, the economic profit of the undersowing was $€ 53.71 \mathrm{ha}^{-1}$ lower than in separate spring and autumn sowing due to lower yields of both barley and winter wheat. In 1997, the barley producer price was $€ 157.43$ $\mathrm{t}^{-1}$ and the price of wheat was $€ 250.04 \mathrm{t}^{-1}$ (Kakko et al., 1997). However, the average producer prices in 2009-2019 have been $€ 155.69 \mathrm{t}^{-1}$ for barley and $€ 173.41 \mathrm{t}^{-1}$ for milling wheat (LUKE (Natural Resources Institute Finland), 2019). Therefore, the difference in economic profit between undersowing and separate sowing methods would be nowadays smaller than 22 years ago, suggesting that undersowing winter wheat to barley could now be more attractive than in 1997.

There were, however, also additional challenges with undersowing winter wheat, namely increased occurrence of Hessian fly [Mayetiola destructor (Say)], which is difficult to control with the common pyrethroids available in Europe. The Hessian fly larvae are usually deep in the base of the plant and therefore cannot be reached with insecticide spray. Seed treatment with an insecticide reduced the number of Hessian flys in winter wheat plants in the experiments of HuuselaVeistola and Känkänen (2000). However, currently there are no insecticide seed treatments registered for use in cereals in Finland [TUKES (Finnish Safety and Chemicals Agency), 2020].

An advantage in relay cropping is the reduced leaching of mineral $\mathrm{N}$ from the agricultural environment. According to Tuulos et al. (2015c), winter turnip rape undersown with barley decreased the amount of soil mineral $\mathrm{NO}_{3}^{-}-\mathrm{N}$ more than $50 \%$ in the topsoil and more importantly $60-80 \%$ in the subsoil, when compared with $\mathrm{NO}_{3}^{-}-\mathrm{N}$ content in the topsoil and subsoil of plots with sole stand barley that was plowed after harvest. Tuulos et al. (2015c) discussed different explanations for the performance in $\mathrm{NO}_{3}^{-}$- $\mathrm{N}$ uptake by barley-winter turnip rape mixed stands and concluded that as crucifers tend to have deeper root systems than Graminae species they are commonly used as catch crops. A deep root system depletes subsoil $\mathrm{NO}_{3}^{-}-\mathrm{N}$ more efficiently than shallow root systems. Combining barley with winter turnip rape in a mixed stand results in a stand with densely distributed plant individuals and roots distributed to different depths in the soil. As a crop undersown already in spring, winter turnip rape has $\sim 10$ more weeks to expand its root system than winter turnip rape sole crops, which are usually established in late summer. This was manifested as a higher amount of depleted subsoil $\mathrm{N}$ in the mixed stands of winter turnip rape and spring barley (Tuulos et al., 2015c).

Another benefit of relay cropping is the reduced need for soil tillage, as crops for two subsequent years are established simultaneously or almost simultaneously. Reduced tillage brings many benefits, including less use of fuel in agriculture and also less detrimental effects on the soil structure.

\section{Spring and Winter Crop Mixtures for Silage}

In cattle production, whole crop cereal silage is also used as a supplement to ordinary grass, legume, or maize based silage. Whole crop cereal silage feeding is common in areas where the cattle's indoor feeding season is long and outdoor feeding season, as well as the whole growing period, are short and variation in the produced amounts and availability of ordinary silage occurs. Usually, whole crop cereal silage is harvested from sole stands of spring or winter cereals, between the late milk and early dough stages (Jedel and Salmon, 1995). Jedel and Salmon (1995) studied spring barley and spring triticale grown as intercrop mixtures with winter triticale and winter rye for silage production in Alberta. As spring-sown winter cereals do not vernalize during the first growing season, the silage from winter-spring cereal mixtures consisted mostly of winter cereal leaves and spring cereal stems, leaves, and heads. Jedel and Salmon (1995) found out that the silage yield of winter-spring cereal mixtures was usually similar to or smaller than the silage yield of the sole crop of the higher yielding component of the mixtures, on average $8.46 \mathrm{t} \mathrm{ha}^{-1}$. Similarly, the silage yield of cereal mixture tends to be equal or slightly lower than the silage yield of monocrops (Baron et al., 1992). However, the silage quality, measured as soluble fiber content, may slightly be improved due to the higher palatability of the vegetative parts of winter cereals in the silage made of mixed crops (Jedel and Salmon, 1995), even if the amount of winter cereal is modest (Baron et al., 1992). However, in a situation where the seeding ratio of winter cereal and spring cereal is $1: 1$, it is likely that the spring cereal dominates the 
winter cereal in a mixed stand and therefore contributes to the formation of total biomass more (Baron et al., 1992), indicating that adjusting the seeding ratio to the benefit of winter cereal could affect silage quality. An additional benefit of mixed stands is that as the silage quality is an intermediate of both components of sole stands, the appropriate time interval for harvesting could be wider than that of sole crops, without compromising yield quality. Regarding dry matter yield and silage quality, spring triticale seemed to be more suitable to mixtures than spring barley (Jedel and Salmon, 1995).

Juskiw et al. (2000) reported that mixtures of spring cultivars of oat, barley, and triticale as well as winter cultivars of rye and triticale had quality attributes intermediate of the sole component in the mixture and would therefore enable a wider harvest window for silage. As an opposite to the work of Jedel and Salmon (1995), increasing the sowing rate did not bring an advantage in the quantity of the silage yield (Juskiw et al., 2000). The most productive mixture was barley-oat intercrop giving slightly higher silage yields than either of the components as sole crops. Winter cereal mixtures tended to be lower yielding than sole stands of the components. Intraspecific variety mixtures, such as some combinations of barley varieties, could be more productive than sole variety stands (Juskiw et al., 2000).

Tuulos et al. (2015a) studied the possibility of harvesting the winter turnip rape leaves when grown mixed with spring cereals and as sole stands. Forage yields of winter turnip rape were in the range of $1,000-3,000 \mathrm{~kg}$ of dry matter ha ${ }^{-1}$, sole stands always yielding the best. When the forage quality was evaluated, the mixed stand had a markedly lower $\mathrm{D}$-value and crude protein and crude fat content but higher dry matter, crude fiber content, and NDF value. The differences were due to the cereal stubble in the mixed crops. The drawback was a weakened overwintering of the plant stands (Tuulos et al., 2015a).

\section{Biennial Crops in Mixed Cropping Systems}

There are few biennial crops of commercial importance in the boreal-nemoral region and few cases of their inclusion in mixed cropping systems. The most important biennial crop in the region is caraway (Carum carvi L.), which is rarely in mixed cropping systems because of the yield penalty, particularly on the second year yield. However, the possibility of using spring wheat, oat, flax, faba bean, and pea as intercrops for caraway has been studied in Finland. Mixed cropping with spring wheat and flax gave an extreme reduction in caraway yield; depending on the row system used, the yield in the second year was as low as under $100 \mathrm{~kg} \mathrm{ha}^{-1}$ and the yield was $\sim 30 \%$ lower in the third year (Keskitalo, 2014). In contrast, mixed cropping with pea, faba bean, and barley, although reducing the second year caraway yield by $30-50 \%$, resulted in, in the third year, up to a 3 -fold higher caraway yield in comparison with a sole caraway crop. Specifically, when in mixed crop with barley or faba bean, caraway yielded $\sim 1,500 \mathrm{~kg} \mathrm{ha}^{-1}$ and with pea $\sim 1,200 \mathrm{~kg} \mathrm{ha}^{-1}$ (Keskitalo, 2014).

In vegetable cropping, there is evidence of some biennial legumes as good alternatives to be included in the mixed cropping systems. For example, yellow sweet clover (Melilotus officinalis L.), hairy vetch (Vicia villosa Roth.), and crimson clover (Trifolium incarnatum L.) were shown to be suitable alternatives in field trials in Norway (Brandsaeter and Netland, 1999; Brandsaeter et al., 2000). In addition, the biennial field cress was selected in Sweden as a potential new oilseed crop and catch crop. Field cress reduced $\mathrm{N}$ leaching remarkably well, leaving a significantly lower mean total $\mathrm{N}$ in soil than other catch crops, such as the mixture of hairy vetch and winter rye, although it had a negative effect on total phosphorus leaching (Ulén and Aronsson, 2018).

Two crops that have gained interest lately again are flax and Jerusalem artichoke (Helianthus tuberosus L.). Flax is an important fiber and oil crop in the region, particularly in Finland and Canada. In Canada, Halde and Entz (2014) grew barley and hairy vetch with and without tillage, and seeding flax the following year. It seems that including crimping of cover crops is effective at stopping the growth of barley but not hairy vetch. Moreover, the success of the system under no-till requires a wellestablished cover crop and an absence of excess soil moisture. Keeping the cover crop biomass until mid-summer harvest was a good strategy and did not cause a yield penalty in the flax crop subsequently harvested (Halde and Entz, 2014).

In Finland, Jerusalem artichoke obtained interest, since the aboveground biomass could be used as bioenergy feedstock. Vetch (Vicia sativa L.), sweet clover (Melilotus albus Medik.), goat's rue (Galega orientalis L.), and red clover were tested as intercrops. Although there were no significant differences between the effect of intercrops on Jerusalem artichoke yields and mineral element composition (compared with $\mathrm{N}$ fertilizer), the dense shade and soil disturbance during the harvest of tubers hindered the durability and ease of use of these intercrops (Epie et al., 2018).

\section{Mixed Cropping Systems Including Catch Crops and Cover Crops}

The use of cover and/or catch crops in mixed cropping systems is a key practice within conservation agriculture, which seeks to protect the soil cover and improve soil function, while preventing nutrient losses and erosion (Lahmar, 2010). Crops that have the ability or are chosen specifically to reduce $\mathrm{N}$ leaching are often referred to as "catch crops" (Valkama et al., 2015), while the umbrella term "cover crops" is used for cases when the crop provides other services, such as preventing phosphorus losses and soil erosion (Aronsson et al., 2016). The term "subsidiary crops," coined in recent years, includes crops that are mainly cultivated because of the range of agroecological benefits they provide rather than for economic profit (Reimer et al., 2019).

The climate in the boreal-nemoral region makes it prone to high $\mathrm{N}$ leaching during winter (Zhao et al., 2020). Thus, it is of utmost importance to reduce soil $N_{3}^{-}-\mathrm{N}$ levels left in autumn and to choose efficient catch crops (Wahlström et al., 2015). The role of cover crops in achieving more sustainable crop rotations has been well-studied, and current environmental policy in the region encourages farmers to often include them in the cropping systems. For example, in Denmark, farmers are required to grow cover crops in autumn on at least $10 \%$ of their farm area (Thorup-Kristensen and Kirkegaard, 2016) and 
in Finland there is an allowance of $€ 100 \mathrm{ha}^{-1}$ for cover crops (Salonen and Ketoja, 2019).

\section{Advantages}

Cover crops increase the vegetation cover in the off-season and have the potential to reduce $\mathrm{NO}_{3}^{-}-\mathrm{N}$ leaching by increasing the uptake of mineral N surplus (Känkänen et al., 2001; De Notaris et al., 2020; Zhao et al., 2020). Moreover, cover crops improve nutrient cycling as their life cycle terminates, since the following crops can reuse the $\mathrm{N}$ and other nutrients (e.g., sulfur, potassium, and phosphorus, among others) left in the surface soil layer and crop residues (Eriksen et al., 2004; Toom et al., 2019; Yang et al., 2019). Although catch crops may affect the cycling of several nutrients, when choosing catch crops the priority is mainly to maximize $\mathrm{N}$ efficiency in the cropping system, and the efficiency of other nutrients is assessed in that perspective (Eriksen et al., 2004; Løes et al., 2011).

Non-legume cover crops are the most effective option to reduce $\mathrm{N}$ leaching. Reducing up to $51-80 \%$ of $\mathrm{N}$ leaching, they are effective in a wide variety of soils and weather conditions (Knudsen et al., 2006; Sapkota et al., 2012; Jabloun et al., 2015; Valkama et al., 2015; Pugesgaard et al., 2017; Vogeler et al., 2019; Yang et al., 2019; De Notaris et al., 2020; Zhao et al., 2020). N leaching varies depending on soil type and rainfall (Askegaard et al., 2005, 2011; Hashemi et al., 2018; Pandey et al., 2018). For example, Askegaard et al. $(2005,2011)$ found that $\mathrm{N}$ leaching was higher in a coarse sandy soil with high rainfall than in a sandy loam with low rainfall.

Although legume cover crops are not as efficient in reducing $\mathrm{N}$ leaching, they are valuable as they fix atmospheric $\mathrm{N}$ and retain $\mathrm{N}$, increasing $\mathrm{N}$ availability for the following crop, and thus reducing the need for external $\mathrm{N}$ fertilizer inputs (De Notaris et al., 2019, 2020; Zhao et al., 2020). Moreover, Pandey et al. (2018) pointed out that besides the effect of soil type and rainfall on $\mathrm{N}$ leaching, the response of $\mathrm{N}$ leaching to $\mathrm{N}$ input is critical, as $\mathrm{N}$ input varies as a consequence of different levels of biological $\mathrm{N}$ fixation by different cover crops and their successful establishment or not.

Mixtures of legumes and non-legumes as catch crops have been tested in order to enhance $\mathrm{N}$ supply for the next crop, and striving for minimum $\mathrm{N}$ leaching risk (Vogeler et al., 2019). It is estimated that while a legume catch crop can reduce $\mathrm{N}$ leaching by $28-55 \%$, a mixture of a non-legume and legume catch crop can reduce leaching by $49-81 \%$, which could outperform the reported values for sole stands of non-legume catch crops (Vogeler et al., 2019). In addition to reducing $\mathrm{N}$ leaching, legume and mixed catch crops are able to increase grain yield and grain $\mathrm{N}$ content by up to $6 \%$ (Valkama et al., 2015).

Several cover crops are credited with improving soil properties including bulk density, aggregate size distribution, water stability of aggregates, and soil organic matter (Breland, 1995; Foereid and Høgh-Jensen, 2004; Bronick and Lal, 2005). Deeper-rooted crops, such as fodder radish (Raphanus raphanistrum subsp. sativus (L.) Domin), have been found to increase gas diffusivity, lower pore tortuosity, and increase soil macroporosity, all of which could potentially ameliorate soil compaction (KadŽienŽ et al., 2011).

Other benefits of cover crops for the soil include a reduction in soil erosion (Dabney, 1998; Känkänen et al., 2001; Vico et al., 2014), reduction in phosphorus losses (Liu et al., 2015), an increase in soil total $\mathrm{N}$ and carbon content (Sapkota et al., 2012), and prevention of drain water acidification (Ulén et al., 2008). Some cover crops may increase the yield of the following crop (Bergkvist et al., 2011) and may help to control weeds in organic farming systems (Peigné et al., 2016; Masilionyte et al., 2017), although their effectiveness in weed control may depend on interactions between the chosen tillage system and choice of cover crops (Reimer et al., 2019).

The combined effect of these advantages often means that catch crops are widely accepted and a proven key management practice for climate and environmentally friendly agricultural policy schemes. Indeed, a survey among farmers in five countries-Denmark, Estonia, Finland, Poland, and Swedenshowed that a catch crop contract would be the most preferred strategy to reduce nutrient leaching and greenhouse gas emissions compared with other measures, such as set-aside and fertilizer technology contracts (Hasler et al., 2019).

\section{Challenges}

In the boreal-nemoral region, depending on the latitude, snow cover and temperatures below zero can last between 3 and 6 months, making cultivation during the off-season difficult. The risk of winter damage in the region is a big constraint for utilizing catch and cover crops in mixed cropping systems, and it is a constant risk due to prolonged snow cover, frequent, and erratic freeze-thaw cycles, and cold and frost spells (Hutchinson et al., 2007; Vico et al., 2014; Yang et al., 2019). In addition, the short and "unreliable" period without snow cover makes the establishment success of cover crops difficult, and nutrient retention in clay soils common in the region is challenging (Liu et al., 2015).

The main challenges in systems with cash or cover crops are to: (a) decide whether to undersow with the main cash crop or sow after the harvest of the cash crop, and (b) choose an appropriate and effective method to terminate the cash or cover crop so that its growth ends in time for the next cash crop to be sown. Undersown cover crops are usually paired with spring cereals (Aronsson et al., 2016). Some alternatives for terminating the cover crop growth are use of herbicides (e.g., glyphosate), plowing (Breland, 1995, 1996), synchronizing the end of the crop with a frost period, and use of roller crimping machinery (Kornecki et al., 2009). Although the latter technique has gained popularity, it does not always succeed in killing all cover crops (Halde and Entz, 2014).

A challenge specific to legume cover crops is that in order for them to be able to improve soil $\mathrm{N}$ availability, there needs to be sufficient biomass accumulation, so early establishment, for example performing undersowing, is of utmost importance (De Notaris et al., 2019). Although the timing of undersowing is critical to maximize biomass and plant $\mathrm{N}$, the best timing for undersowing has been tested in very few studies. Early sowing is reported to achieve $\mathrm{N}$ fertilizer replacement values of $\sim 40 \mathrm{~N}$ $\mathrm{kg} \mathrm{ha}^{-1}$ and biological $\mathrm{N}$ fixation rates of up to $85 \%$ of $\mathrm{N}$ accumulated in the cover crop biomass. In such a scenario, $\mathrm{N}$ supply and long-term soil fertility are improved and could result in a "yield stabilization effect" over time (De Notaris et al., 
2019). However, mixtures of cover crops that include legumes need careful planning in aspects such as increased interrow spacing to reduce the competition between crops and minimize the impact of cover crops on the main crop yield (De Notaris et al., 2019). The impact of both legume and non-legume catch crops undersown in spring on grain yields has been reviewed by Valkama et al. (2015) who did a meta-analysis of 35 studies in the Nordic countries. According to them (Valkama et al., 2015), Italian ryegrass was the best catch crop, depleting up to $60 \%$ of soil $\mathrm{N}$ and being more effective than perennial ryegrass.

When using catch and cover crops, it is common that grain yields of the main cash crop in the first year are decreased (Breland, 1996; Cicek et al., 2015; Yang et al., 2019). This yield penalty is often equated to the density of the catch crop, meaning that a denser cover crop frequently leads to a bigger yield penalty of the main cash crop; thus choosing the suitable cover crop should go hand-in-hand with customizing the interrow spacing (Breland, 1996; De Notaris et al., 2019).

The use of and research into catch and cover crops has been widely explored in southern Sweden, Denmark, and Canada, while less so in Finland, Norway, Estonia, Latvia, and Lithuania. The most effective cover and catch crops in the region are perennial ryegrass, Italian ryegrass (Lolium multiflorum Lam.), white clover, red clover, hairy vetch, fodder radish, winter rye, winter oilseed rape, and white mustard (Sinapis alba L.). Further details about the main crops used in rotation and the benefit of cover crops for the mixed cropping system are listed in Tables S1, S2.

\section{CONCLUSIONS}

Crop mixtures have a long tradition in cropping systems in the boreal-nemoral region, although for decades these have been neglected in practical crop production. In the future challenges associated with climate change, both environmental and economic, crop mixtures could provide a sustainable option for increased resilience of crop production especially since crop mixtures can decrease nutrient leaching and pathogen and weed

\section{REFERENCES}

Altieri, M. A., and Liebman, M. (1986). "Insect, weed and plant disease management in multiple cropping systems," in Multiple Cropping Systems, ed C. A. Francis (New York, NY: Macmillan Publishing Company), 183-218.

Andersen, M. K., Hauggaard-Nielsen, H., Ambus, P., and Jensen, E. S. (2005). Biomass production, symbiotic nitrogen fixation and inorganic $\mathrm{N}$ use in dual and tri-component annual intercrops. Plant Soil 266, 273-287. doi: 10.1007/s11104-005-0997-1

Andersen, M. K., Hauggaard-Nielsen, H., Weiner, J., and Jensen, E. S. (2007). Competitive dynamics in two- and three-component intercrops. J. Appl. Ecol. 44, 545-551. doi: 10.1111/j.1365-2664.2007.01289.x

Annicchiarico, P., Collins, R. P., De Ron, A. M., Firmat, C., Litrico, I., and Hauggaard-Nielsen, H. (2019). Do we need specific breeding for legume-based mixtures? Adv. Agron. 147, 141-215. doi: 10.1016/bs.agron.2019.04.001

Anonymous (2020). Time and Date. Available online at: https://www.timeanddate. com/weather/lithuania/vilnius/climate (accessed March 19, 2020).

Aronsson, H., Hansen, E. M., Thomsen, I. K., Ogaard, A. F., Känkänen, H., and Ulén, B. (2016). The ability of cover crops to reduce nitrogen and phosphorus infestation, and thus the need for agrochemicals, as well as increase the availability of $\mathrm{N}$ among other nutrients, and yield stability. However, in order to reach wider acceptability in practice, also the end users, such as industry, should develop the means to utilize the raw materials resulting from mixed cropping systems. Although the advantages of mixed cropping are clear, challenges in the boreal-nemoral region are set by the climatic conditions restricting the seeding and harvesting times, the length of the growing season, and thus the limited availability of suitable crops. Therefore, further research is needed to find the most suitable species, cultivars, and management practices for crop mixtures for different purposes as well as to gather information regarding the ecological, economic, and environmental effects of these mixtures.

\section{AUTHOR CONTRIBUTIONS}

CL, AT, VJ, and PM equally wrote sections of the manuscript. All authors contributed to the article and approved the submitted version.

\section{FUNDING}

CL was funded by the Finnish Association of Academic Agronomists' grant Suomi kasvaa ruoasta (Oiva Kuusisto Foundation).

\section{ACKNOWLEDGMENTS}

The authors want to thank Mr. Ari Virtanen for his constructive comments while preparing the manuscript.

\section{SUPPLEMENTARY MATERIAL}

The Supplementary Material for this article can be found online at: https://www.frontiersin.org/articles/10.3389/fsufs. 2020.00103/full\#supplementary-material losses from arable land in southern Scandinavia and Finland. J. Soil Water Conserv. 71, 41-55. doi: 10.2489/jswc.71.1.41

Askegaard, M., Olesen, J. E., and Kristensen, K. (2005). Nitrate leaching from organic arable crop rotations: effects of location, manure and catch crop. Soil Use Manage. 21, 181-188. doi: 10.1079/SUM20 05315

Askegaard, M., Olesen, J. E., Rasmussen, I. A., and Kristensen, K. (2011). Nitrate leaching from organic arable crop rotations is mostly determined by autumn field management. Agric. Ecosyst. Environ. 142, 149-160. doi: 10.1016/j.agee.2011.04.014

Baldocchi, D., Kelliher, F. M., Black, T. A., and Jarvis, P. (2000). Climate and vegetation controls on the boreal zone energy exchange. Glob. Change Biol. 6, 69-83. doi: 10.1046/j.1365-2486.2000.06014.x

Baron,V. S., Najda, H. G., Salmon, D. F., and Dick, A.C. (1992). Post-flowering forage potential of spring and winter cereal mixtures. Can. J. Plant Sci. 72, 137-145. doi: 10.4141/cjps92-014

Bélanger, G., Castonguay, Y., and Lajeunesse, J. (2014). Benefits of mixing timothy with alfalfa for forage yield, nutritive value, and weed suppression in northern environments. Can. J. Plant Sci. 94, 51-60. doi: 10.4141/cjps2013-228 
Bergkvist, G., Stenberg, M., Wetterlind, J., Båth, B., and Elfstrand, S. (2011). Clover cover crops under-sown in winter wheat increase yield of subsequent spring barley-effect of N dose and companion grass. Field Crops Res. 120, 292-298. doi: 10.1016/j.fcr.2010.11.001

Bertrand, A., Tremblay, G. F., Pelletier, S., Castonguay, Y., and Bélanger, G. (2008). Yield and nutritive value of timothy as affected by temperature, photoperiod and time of harvest. Grass Forage Sci. 63, 421-432. doi: 10.1111/j.1365-2494.2008.00649.x

Black, J. N. (1963). The interrelationship of solar radiation and leaf area index in determining the rate of dry matter production of swards of subterranean clover (Trifolium subterraneum L.). Aust. J. Agric. Res. 14, 20-38. doi: 10.1071/AR9630020

Brandsaeter, L. O., and Netland, J. (1999). Winter annual legumes for use as cover crops in row crops in Northern regions: I. Field experiments. Crop Sci. 39, 1369-1379. doi: 10.2135/cropsci1999.3951369x

Brandsaeter, L. O., Smeby, T., Tronsmo, A. M., and Netland, J. (2000). Winter annual legumes for use as cover crops in row crops in Northern regions: II. Frost resistance study. Crop Sci. 40, 175-181. doi: 10.2135/cropsci2000.401175x

Breland, T. A. (1995). Green manuring with clover and ryegrass catch crops undersown in spring wheat: effects on soil structure. Soil Use Manage. 11, 163-167. doi: 10.1111/j.1475-2743.1995.tb00950.x

Breland, T. A. (1996). Green manuring with clover and ryegrass catch crops undersown in small grains: effects on soil mineral nitrogen in field and laboratory experiments. Acta Agric. Scand., Sect. B Soil Plant Sci. 46, 178-185. doi: 10.1080/09064719609413131

Bronick, C. J., and Lal, R. (2005). Soil structure and management: a review. Geoderma 124, 3-22. doi: 10.1016/j.geoderma.2004.03.005

Carlsson, G., and Huss-Danell, K. (2003). Nitrogen fixation in perennial forage legumes in the field. Plant Soil. 253, 353-372. doi: 10.1023/A:1024847017371

Cicek, H., Thiessen Martens, J. R., Bamford, K. C., and Entz, M. H. (2015). Lateseason catch crops reduce nitrate leaching risk after grazed green manures but release N slower than wheat demand. Agric. Ecosyst. Environ. 202, 31-41. doi: 10.1016/j.agee.2014.12.007

Dabney, S. M. (1998). Cover crop impacts on watershed hydrology. Soil Water Conserv. 53, 207-213.

Dahlin, A. S., and Stenberg, M. (2010). Transfer of N from red clover to perennial ryegrass in mixed stands under different cutting strategies. Eur. J. Agron. 33, 149-156. doi: 10.1016/j.eja.2010.04.006

Davidson, J. L., Jones, D. B., and Christian, K. R. (1990). Winter feed production and grain yield in mixtures of spring and winter wheats. Aust. J. Agric. Res. 41, 1-18. doi: 10.1071/AR9900001

Davies, J. H. C., Woolley, J. N., and Moreno, R. A. (1986). "Multiple cropping with legumes and starchy roots," in Multiple Cropping Systems, ed C. A. Francis (New York, NY: Macmillan Publishing Company), 133-160.

De Notaris, C., Olesen,. J. E., Sørensen, P., and Rasmussen, J. (2020). Input and mineralization of carbon and nitrogen in soil from legume-based cover crops. Nutr. Cycl. Agroecosyst. 116, 1-18. doi: 10.1007/s10705-019-10026-z

De Notaris, C., Rasmussen, J., Sørensen, P., Melander, B.o., and Olesen, J. E. (2019). Manipulating cover crop growth by adjusting sowing time and cereal interrow spacing to enhance residual nitrogen effects. Field Crops Res. 234, 15-25. doi: 10.1016/j.fcr.2019.02.008

Deveikyte, I., Kadziuliene, Z., and Sarunaite, L. (2009). Weed suppression ability of spring crops and peas in pure and mixed stands. Agron. Res. 7, 239-244.

Dhamala, N. R., Eriksen, J., Carlsson, G., Søegaard, K., and Rasmussen, J. (2017). Highly productive forage legume stands show no positive biodiversity effect on yield and $\mathrm{N}_{2}$-fixation. Plant Soil 417, 169-182. doi: 10.1007/s11104-017-3249-2

Dhamala, N. R., Rasmussen, J., Carlsson, G., Søegaard, K., and Eriksen, J. (2018). Effects of including forbs on $\mathrm{N}_{2}$-fixation and $\mathrm{N}$ yield in red clover-ryegrass mixtures. Plant Soil 424, 525-537. doi: 10.1007/s11104-017-3554-9

Dinnes, D. L., Karlen, D. L., Jaynes, D. B., Kaspar, T. C., Hatfield, J. L., Colvin, T. S., et al. (2002). Nitrogen management strategies to reduce nitrate leaching in tiledrained midwestern soils. Agron. J. 94, 153-171. doi: 10.2134/agronj2002.1530

Epie, K. E., Santanen, A., Mäkel,ä, P., and Stoddard, F. (2018). Fertilizer and intercropped legumes as nitrogen source for Jerusalem artichoke (Helianthus tuberosus L.) tops for bioenergy. Agric. Food Sci. 27, 199-205. doi: 10.23986/afsci.70110

Ergon, Å., Kirwan, L., Bleken, M. A., Skjelvåg, A. O., Collins, R. P., and Rognli, O. A. (2016). Species interactions in a grassland mixture under low nitrogen fertilization and two cutting frequencies: 1 . Dry-matter yield and dynamics of species composition. Grass Forage Sci. 71, 667-682. doi: 10.1111/gfs.12250

Eriksen, J., Mortensen, T., and Søegaard, K. (2012). Root biomass and carbon storage in differently managed multispecies temporary grasslands. Grassl. Sci Eur. 17, 610-612.

Eriksen, J., Thorup-Kristensen, K., and Askegaard, M. (2004). Plant availability of catch crop sulfur following spring incorporation. J. Plant Nutr. Soil Sci. 167, 609-615. doi: 10.1002/jpln.200420415

Finn, J. A., Kirwan, L., Connolly, J., Sebastia, M. T., Helgadóttir, A., Baadshaug, O. H., et al. (2013). Ecosystem function enhanced by combining four functional types of plant species in intensively managed grassland mixtures: a 3-year continental-scale field experiment. J. Appl. Ecol. 50, 365-375. doi: $10.1111 / 1365-2664.12041$

FMI (Finnish Meteorological Institute) (2020). Seasons in Finland. Available online at: https://en.ilmatieteenlaitos.fi/seasons-in-finland (accessed March 19, 2020).

Foereid, B., and Høgh-Jensen, H. (2004). Carbon sequestration potential of organic agriculture in northern Europe-a modelling approach. Nutr. Cycl. Agroecosyst. 68, 13-24. doi: 10.1023/B:FRES.0000012231.89516.80

Frame, J., and Laidlaw, A. S. (2011). Improved Grassland Management, 2nd Edn. Ramsbury: The Crowood Press Ltd.

Francis, C. A. (1986). "Introduction: distribution and importance of multiple cropping," in Multiple Cropping Systems, ed C. A. Francis (New York, NY: Macmillan Publishing Company), 1-19.

Frankow-Lindberg, B. E., Brophy, C., Collins, R. P., and Connolly, J. (2009). Biodiversity effects on yield and unsown species invasion in a temperate forage ecosystem. Ann. Bot. 103, 913-921. doi: 10.1093/aob/mcp008

Fukai, S., and Trenbath, B. R. (1993). Processes determining intercrop productivity and yields of component crops. Field Crops Res. 34, 247-271. doi: 10.1016/0378-4290(93)90117-6

Ghaley, B. B., Hauggaard-Nielsen, H., Høgh-Jensen, H., and Jensen, E. S. (2005). Intercropping of wheat and pea as influenced by nitrogen fertilizer. Nutr. Cycl. Agroecosyst. 73, 201-212. doi: 10.1007/s10705-005-2475-9

Hagen, D., Svavarsdottir, K., Nilsson, C., Tolvanen, A. K., Raulund-Rasmussen, K., Aradòttir, À. L., et al. (2013). Ecological and social dimensions of ecosystem restoration in the Nordic countries. Ecol. Soc. 18:34. doi: 10.5751/ES-05891-180434

Halde, C., and Entz, M. H. (2014). Flax (Linum usitatissimum L.) production system performance under organic rotational no-till and two organic tilled systems in a cool sub-humid continental climate. Soil Tillage Res.143, 145-154. doi: 10.1016/j.still.2014.06.009

Harper, F. (1983). Principles of Arable Crop Production. Bungay: Granada Publishing.

Hashemi, F., Olesen, J. E., Børgesen, C. D., Tornbjerg, H., Thodsen, H., and Dalgaard, T. (2018). Potential benefits of farm scale measures versus landscape measures for reducing nitrate loads in a Danish catchment. Sci. Total Environ. 637-638, 318-335. doi: 10.1016/j.scitotenv.2018.04.390

Hasler, B., Czajkowski, M., Elofsson, K., Hansen, L. B., Konrad, M. T., Nielsen, H. ø., et al. (2019). Farmers' preferences for nutrient and climate-related agrienvironmental schemes: a cross-country comparison. Ambio 48, 1290-1303. doi: 10.1007/s13280-019-01242-6

Hauggaard-Nielsen, H., Ambus, P., and Jensen, E. S. (2001). Interspecific competition, $\mathrm{N}$ use and interference with weeds in pea-barley intercropping. Field Crops Res.70, 101-109. doi: 10.1016/S0378-4290(01)00126-5

Hauggaard-Nielsen, H., Ambus, P., and Jensen, E. S. (2003). The comparison of nitrogen use and leaching in sole cropped versus intercropped pea and barley. Nutr. Cycl. Agroecosyst. 65, 289-300. doi: 10.1023/A:1022612528161

Hauggaard-Nielsen, H., Andersen, M. K., Jørnsgaard, B., and Jensen, E. S. (2006). Density and relative frequence efects on competitive interactions and resource use in pea-barley intercrops. Field Crops Res. 95, 256-267. doi: $10.1016 /$ j.fcr.2005.03.003

Hauggaard-Nielsen, H., and Jensen, E. S. (2001). Evaluating pea and barley cultivars for complementarity in intercropping at different levels of soil N availability. Field Crops Res. 72, 185-196. doi: 10.1016/S0378-4290(01)0 0176-9

Hauggaard-Nielsen, H., Jørnsgaard, B., Kinane, J., and Jensen, E. S. (2008). Grain legume-cereal intercropping: the practical application of diversity, competition and facilitation in arable and organic cropping systems. Renew. Agric. Food Syst. 23, 3-12. doi: 10.1017/S1742170507002025 
Heikkilä, M., and Seppä, H. (2003). A 11,000 yr palaeotemperature reconstruction from the southern boreal zone in Finland. Quat. Sci. Rev. 22, 541-554. doi: 10.1016/S0277-3791(02)00189-0

Heikkilä, T., Toivonen, V., and Mela, T. (1992). "Comparison of red clovergrass silage with grass silage for milk production," in Proceedings of 14th General Meeting of the European Grassland Federation, eds P. Pärssinen, O. Niemeläinen, L. Tervonen, and S. Lehtinen (Lahti), 388-391.

Helenius, J. (1990). Plant size, nutrient composition and biomass productivity of oats and faba bean in intercropping, and the effect of controlling Rhopalosiphum padi (Hom., Aphidae) on these properties. J. Agric. Sci. Finl. 62, 21-31. doi: 10.23986/afsci.72921

Helenius, J., and Ronni, P. (1989). Yield, its components and pest incidence in mixed intercropping of oats (Avena sativa) and field beans (Vicia faba). J. Agric. Sci. Finl. 61, 15-31. doi: 10.23986/afsci.72348

Helgadóttir, Á., Aavola, R., Isolahti, M., Marum, P., Persson, C., Aleliunas, A., et al. (2018a). Adaptability and phenotypic stability of Lolium perenne L. cultivars of diverse origin grown at the margin of the species distribution. J. Agron. Crop Sci. 204, 493-504. doi: 10.1111/jac.12273

Helgadóttir, Á., Suter, M., Gylfadóttir, T., Kristjánsdóttir, T., and Luscher, A. (2018b). Grass-legume mixtures sustain strong yield advantage over monocultures under cool maritime growing conditions over a period of 5 years. Ann. Bot. 122, 337-348. doi: 10.1093/aob/mcy074

Hummel, J. D., Dosdall, L. M., Clayton, G. W., Turkington, T. K., Lupwayi, N. Z., Neil Harker, K., et al. (2009). Canola-wheat intercrops for improved agronomic performance and integrated pest management. Agron. J. 101, 1190-1997. doi: 10.2134 /agronj2009.0032

Humphreys, M. W., Macleod, C. J. A., Whalley, W. R., Turner, L. B., Farrell, M. S., Ghesquière, M., et al. (2013). "Designing grass cultivars for droughts and floods," in Breeding Strategies for Sustainable forage and Turf Grass Improvement, eds D. Barth, and S. Milbourne (Dordrecht: Springer Netherlands), 171-179. doi: 10.1007/978-94-007-4555-1_21

Hutchinson, J. J., Campbell, C. A., and Desjardins, R. L. (2007). Some perspectives on carbon sequestration in agriculture. Agric. For. Meteorol. 142, 288-302. doi: 10.1016/j.agrformet.2006.03.030

Huusela-Veistola, E., and Känkänen, H. (2000). Relay intercropping of cereals in Finland: prospects and problems. Asp. Appl. Biol. 62, 95-100.

Jabloun, M., Schelde, K., Tao, F., and Olesen, J. E. (2015). Effect of temperature and precipitation on nitrate leaching from organic cereal cropping systems in Denmark. Eur. J. Agron. 62, 55-64. doi: 10.1016/j.eja.2014. 09.007

Jedel, P. E., and Salmon, D. F. (1995). Forage potential of spring and winter cereal mixtures in a short-season growing area. Agron. J. 87, 731-736. doi: 10.2134/agronj1995.00021962008700040020x

Jensen, E. S. (1996). Grain yield, symbiotic $\mathrm{N}_{2}$ fixation and interspecific competition for inorganic $\mathrm{N}$ in pea-barley intercrops. Plant Soil 182, 25-38. doi: 10.1007/BF00010992

Jokinen, K. (1991a). Yield and competition in barley variety mixtures. J. Agric. Sci. Finl. 63, 287-305. doi: 10.23986/afsci.72404

Jokinen, K. (1991b). Assessment of competition and yield advantage in addition series of barley variety mixtures. J. Agric. Sci. Finl. 63, 307-320. doi: $10.23986 /$ afsci.72405

Jokinen, K. (1991c). Competition and yield performance in mixtures of oats and barley - nitrogen fertilization, density and proportion of the components. J. Agri. Sci. Finl. 63, 321-340. doi: 10.23986/afsci.72406

Jokinen, K. (1991d). Influence of different barley varieties on competition and yield performance in barley-oats mixtures at two levels of nitrogen fertilization. J. Agric. Sci. Finl. 63, 341-351. doi: 10.23986/afsci.72407

Juskiw, P. E., Helm, J. H., and Salmon, D. F. (2000). Forage yield and quality for monocrops and mixtures of small grain cereals. Crop Sci. 40, 138-147. doi: $10.2135 /$ cropsci2000.401138x

KadŽienŽ, G., Munkholm, L. J., and Mutegi, J. K. (2011). Root growth conditions in the topsoil as affected by tillage intensity. Geoderma 166, 66-73. doi: 10.1016/j.geoderma.2011.07.013

Kakko, J., Virtanen, A., and Peltonen, J. (1997). Kevät- ja syysviljojen vuorosekaviljelytekniikan (kaksoiskylvötekniikan) kehittäminen Suomen kasvuoloihin. Loppuraportti. Loimaa: KTTK Siementarkastusosasto. (in Finnish).
Känkänen, H., and Eriksson, C. (2007). Effects of undersown crops on soil mineral N and grain yield of spring barley. Eur. J. Agron. 27, 25-34. doi: 10.1016/j.eja.2007.01.010

Känkänen, H., Eriksson, C., Räkköläinen, M., and Vuorinen, M. (2001). Effect of annually repeated undersowing on cereal grain yields. Agric. Food Sci. Finl. 10, 197-208. doi: 10.23986/afsci.5693

Karjalainen, R. (1986). Spring wheat mixtures in northern crop production: ability of mixtures to buffer disease development and yield loss caused by Septoria nodorum. J. Agric. Sci. Finl. 58, 33-42. doi: 10.23986/afsci.72218

Keating, B. A., and Carberry, P. S. (1993). Resource capture and use in intercropping: solar radiation. Field Crops Res. 34, 273-301. doi: 10.1016/0378-4290(93)90118-7

Keskitalo, M. (2014). "Vaihtoehtoja viljelyjärjestelmiin," in Kumina Tuotantokasvina, ed M. Keskitalo (Tampere: Tampereen Yliopistopaino Juvenes Print Oy), 54-59.

Knudsen, M. T., Hauggaard-Nielsen, H., Jørnsgård, B., and Jensen, E. S. (2004). Comparison of interspecific competition and $\mathrm{N}$ use in pea-barley, faba beanbarley and lupin-barley intercrops grown at two temperate locations. J. Agric. Sci. 142, 617-627. doi: 10.1017/S0021859604004745

Knudsen, M. T., Kristensen, I. S., Berntsen, J., Petersen, B. M., and Kristensen, E. S. (2006). Estimated $\mathrm{N}$ leaching losses for organic and conventional farming in Denmark. J. Agric. Sci. 144, 135-149. doi: 10.1017/S0021859605005812

Kornecki, T. S., Price, A. J., Raper, R. L., and Arriaga, F. L. (2009). New roller crimper concepts for mechanical termination of cover crops in conservation agriculture. Ren. Agric. Food Syst. 24, 165-173. doi: $10.1017 /$ S1742170509002580

Lahmar, R. (2010). Adoption of conservation agriculture in Europe: lessons of the KASSA project. Land Use Policy 27, 4-10. doi: 10.1016/j.landusepol.2008.02.001

Lauk, R., and Lauk, E. (2008). Pea-oat intercrops are superior to pea-wheat and pea-barley intercrops. Acta Agric. Scand. Sect. B Soil Plant Sci. 58, 139-144. doi: 10.1080/09064710701412692

Lauk, R., and Lauk, E. (2009). Dual intercropping of common vetch and wheat or oats, effect on yields and interspecific competition. Agron. Res. 7, 21-32.

Li, H., Penttinen, P., Mikkola, H., and Lindström, K. (2019). Advantages of grass-legume mixture for improvement of crop growth and reducing potential nitrogen loss in a boreal climate. Agric. Food Sci. 28, 176-189. doi: $10.23986 /$ afsci. 75600

Liu, J., Bergkvist, G., and Ulén, B. (2015). Biomass production and phosphorus retention by catch crops on clayey soils in southern and central Sweden. Field Crops Res. 171, 130-137. doi: 10.1016/j.fcr.2014.11.013

Løes, A. K., Henriksen, T. M., Eltun, R., and Sjursen, H. (2011). Repeated use of green-manure catch crops in organic cereal production - grain yields and nitrogen supply. Acta Agric. Scand. Sect. B Soil Plant Sci. 61, 164-175. doi: $10.1080 / 09064711003655509$

LUKE (Natural Resources Institute Finland) (2019). Statistics Database. Available online at: http://statdb.luke.fi/PXWeb/pxweb/en/LUKE/?rxid=9784bbed252e-497f-9a15-345be648b947 (accessed March 16, 2020).

Mäkelä, P. S. A., Tuulos, A., Turakainen, M., and Stoddard, F. L. (2011). Revitalizing the winter turnip rape crop in the northern latitudes. Acta Agric. Scand. B Soil Plant Sci. 61, 195-201. doi: 10.1080/09064711003747470

Mäkinen, H., Kaseva, J., Virkajärvi, P., and Kahiluoto, H. (2018). Gaps in the capacity of modern forage crops to adapt to the changing climate in northern Europe. Mitig. Adapt. Strat. Global Change 23, 81-100. doi: $10.1007 / \mathrm{s} 11027-016-9729-5$

Malhi, S. S. (2012). Improving crop yield, $N$ uptake and economic returns by intercropping barley or canola with pea. Agric. Sci. 3, 1023-1033. doi: $10.4236 /$ as.2012.38124

Masilionyte, L., Maiksteniene, S., Kriauciuniene, Z., Jablonskyte-Rasce, D., Zou, L., and Sarauskis, E. (2017). Effect of cover crops in smothering weeds and volunteer plants in alternative farming systems. Crop Protect. 91, 74-81. doi: $10.1016 / j . c r o p r o .2016 .09 .016$

Mela, T. (2003). Red clover grown in a mixture with grasses: yield, persistence and dynamics of quality characteristics. Agric. Food Sci. 12, 195-212. doi: 10.23986/afsci.5752

Merker, A., Eriksson, D., and Bertholdsson, N.-O. (2010). Barley yield increases with undersown Lepidium campestre. Acta Agric. Scand. B Soil Plant Sci. 60 , 296-273. doi: 10.1080/09064710902903747 
Metzger, M. J., Shkaruba, A. D., Jongman, R. H. G., and Bunce, R. G. H. (2012). Descriptions of the European Environmental Zones and Strata. Alterra Report 228. Wageningen Environmental Research (Alterra).

Midmore, D. J. (1993). Agronomic modification of resource use and intercrop productivity. Field Crops Res. 34, 357-380. doi: 10.1016/0378-4290(93)90122-4

Morris, R. A., and Garrity, D. P. (1993a). Resource capture and utilization in intercropping: water. Field Crops Res. 34, 303-317. doi: 10.1016/0378-4290(93)90119-8

Morris, R. A., and Garrity, D. P. (1993b). Resource capture and utilization in intercropping: non-nitrogen nutrients. Field Crops Res. 34, 319-334. doi: 10.1016/0378-4290(93)90120-C

Nordestgaard, A. (1982). Udloegsmetoder for Vinterraps. Statens Planteavlsforsøg. Meddelelse 1674. Roskilde: Landbrugscentret.

Pandey, A., Li, F., Askegaard, M., Rasmussen, I. A., and Olesen, J. E. (2018). Nitrogen balances in organic and conventional arable crop rotations and their relations to nitrogen yield and nitrate leaching losses. Agric. Ecosyst. Environ. 265, 350-362. doi: 10.1016/j.agee.2018.05.032

Peigné, J., Casagrande, M., Payet, V., David, C., Sans, F. X., Blanco-Moreno, J. M., et al. (2016). How organic farmers practice conservation agriculture in Europe. Renew. Agric. Food Syst. 31, 72-85. doi: 10.1017/S1742170514000477

Pirhofer-Walzl, K., Rasmussen, J., Høgh-Jensen, H., Eriksen, J., Søegaard, K., and Rasmussen, J. (2012). Nitrogen transfer from forage legumes to nine neighbouring plants in a multispecies grassland. Plant Soil 350, 71-84. doi: $10.1007 / \mathrm{s} 11104-011-0882-\mathrm{Z}$

Pirhofer-Walzl, K., Søegaard, K., Høgh-Jensen, H., Eriksen, J., Sanderson, M., and Rasmussen, J. (2011). Forage herbs improve mineral composition of grassland herbage. Grass Forage Sci. 66, 415-423. doi: 10.1111/j.1365-2494.2011.00799.x

Plucknett, D. L., and Smith, N. J. H. (1986). "Historical perspectives of multiple cropping," in Multiple Cropping Systems, ed C. A. Francis (New York, NY: Macmillan Publishing Company), 20-39.

Pridham, J. C., and Entz, M. H. (2008). Intercropping spring wheat with cereal grains, legumes, and oilseeds fails to improve productivity under organic management. Agron. J. 100, 1436-1442. doi: 10.2134/agronj2007.0227

Proagria (2017). Finnish Advisory Group Blog. Available online at: https://www. proagria.fi/blogit/ruohonjuurella/2017/09/26/sikuri-on-maata-parantavayrtti (accessed March 28, 2020).

Pugesgaard, S., Petersen, S. O., Chirinda, N., and Olesen, J. E. (2017). Crop residues as driver for $\mathrm{N}_{2} \mathrm{O}$ emissions from a sandy loam soil. Agric. For. Meteorol. 233, 45-54. doi: 10.1016/j.agrformet.2016.11.007

Rasmussen, J., Søegaard, K., Pirhofer-Walzl, K., and Eriksen, J. (2012). N2-fixation and residual $\mathrm{N}$ effect of four legume species and four companion grass species. Eur. J. Agron. 36, 66-74. doi: 10.1016/j.eja.2011.09.003

Reimer, M., Ringselle, B., Bergkvist, G., Westaway, S., Wittwer, R., Baresel, J. P., et al. (2019). Interactive effects of subsidiary crops and weed pressure in the transition period to non-inversion tillage, a case study of six sites across northern and central Europe. Agron. 9:9. doi: 10.3390/agronomy9090495

Salonen, J., and Ketoja, E., (2019). Undersown cover crops have limited weed suppression potential when reducing tillage intensity in organically grown cereals. Org. Agric. 10, 107-121. doi: 10.1007/s13165-019-00262-6

Sapkota, T. B., Askegaard, M., Laegdsmand, M., and Olesen, J. E. (2012). Effects of catch crop type and root depth on nitrogen leaching and yield of spring barley. Field Crops Res. 125, 129-138. doi: 10.1016/j.fcr.2011.09.009

Sarunaite, L., Deveikyte, I., and Kadziuliene, Z. (2010). Intercropping spring wheat with grain legume for increased production in an organic crop rotation. Agric. 97, 51-58.

Seppänen, M. M., Pakarinen, K., Jokela, V., Anderssen, J. R., Fiil, A., Santanen, A., et al. (2010). Vernalization response of phleum pratense and its relationships to stem lignification and floral transition. Ann. Bot. 106, 697-707. doi: $10.1093 / \mathrm{aob} / \mathrm{mcq} 174$

Silvertown, J. W. (1982). Introduction to Plant Population Ecology. Essex: Longman House.

Stoltz, E., Wallenhammar, A.-C., and Nadeau, E. (2018). Functional divergence effects of intercropped faba bean and maize in organic production for forage increase mineral contents and reduces leaf spots. Agric. Food Sci. 27, 110-123. doi: 10.23986/afsci.66541

Strydhorst, S. M., King, J. R., Lopetinsky, K. J., and Harker, K. N. (2008). Forage potential of intercropping barley with faba bean, lupin, or field pea. Agron. J. 100, 182-190. doi: 10.2134/agronj2007.0197
Sturludóttir, E., Brophy, C., Bélanger, G., Gustavsson, A.-M., Jørgensen, M., Lunnan, T., et al. (2013). Benefits of mixing grasses and legumes for herbage yield and nutritive value in Northern Europe and Canada. Grass Forage Sci. 69, 229-240. doi: 10.1111/gfs.12037

Szumigalski, A. R., and Van Acker, R. C. (2005). Weed suppression and crop production in annual intercrops. Weed Sci. 53, 813-825. doi: 10.1614/WS-05-014R.1

Szumigalski, A. R., and Van Acker, R. C. (2006). Nitrogen yield and land use efficiency in annual sole crops and intercrops. Agron. J. 98, 1030-1040. doi: 10.2134/agronj2005.0277

Szumigalski, A. R., and Van Acker, R. C. (2008). Land equivalent ratios, light interception, and water use in annual intercrops in the presence or absence of in-crop herbicides. Agron. J. 100, 1145-1154. doi: 10.2134/agronj2006.0343

Thompson, D. (2013). Yield and nutritive value of irrigated tall fescue compared with orchardgrass: in monocultures or mixed with alfalfa. Can. J. Plant. Sci. 93, 799-807. doi: 10.4141/cjps2012-283

Thorup-Kristensen, K., and Kirkegaard, J. (2016). Root system-based limits to agricultural productivity and efficiency: the farming systems context. Ann. Bot. 118, 573-592. doi: 10.1093/aob/mcw122

Thorup-Kristensen, K., and Nielsen, N. E. (1998). Modelling and measuring the effect of nitrogen catch crops on the nitrogen supply for succeeding crops. Plant Soil 203, 79-89. doi: 10.1023/A:1004398131396

Toom, M., Talgre, L., Mäe, A., Tamm, S., Narits, L., Edesi, L., et al. (2019). Selecting winter cover crop species for northern climatic conditions. Biol. Agric. Hortic. 35, 263-274. doi: 10.1080/01448765.2019.1627908

Trenbath, B. R. (1993). Intercropping for the management of pests and diseases. Field Crops Res. 34, 381-405. doi: 10.1016/0378-4290(93)90123-5

TUKES (Finnish Safety and Chemicals Agency) (2020). Plant Protection Product Register. Available online at: https://kasvinsuojeluaineet.tukes.fi/ (accessed January 1, 2020).

Tuulos, A., Turakainen, M., Jaakkola, S., Kleemola, J., and Mäkelä, P. (2015a). Forage and seed yield of winter turnip rape established as a mixed crop with cereals. J. Agric. Sci. Camb. 153, 222-235. doi: 10.1017/S002185961400015X

Tuulos, A., Turakainen, M., Kleemola, J., and Mäkelä, P. (2015b). Yield of spring cereals in mixed stands with undersown winter turnip rape. Field Crops Res. 174, 71-78. doi: 10.1016/j.fcr.2015.01.013

Tuulos, A., Yli-Halla, M., Stoddard, F., and Mäkelä, P. (2015c). Winter turnip rape as a soil scavenging catch crop in a cool humid climate. Agron. Sust. Devel. 35, 359-366. doi: 10.1007/s13593-014-0229-2

Tveito, O. E., Forland, E. J., Alexandersson, H., Drebs, A., Jónsson, T., et al. (2001). Nordic Climate Maps. NORDKLIM Report 06/01, Oslo: DNMI.

Ulén, B., and Aronsson, H. (2018). Nitrogen and phosphorus leaching under the potential biennial oilseed plant Lepidium campestre L. in a field trial. Acta Agric. Scand., Sect. B Soil Plant Sci. 68, 555-561. doi: 10.1080/09064710.2018.1444786

Ulén, B., Johansson, G., and Simonsson, M. (2008). Changes in nutrient leaching and groundwater quality during long-term studies of an arable field on the Swedish south-west coast. Hydrol. Res. 39, 63-77. doi: 10.2166/nh.2008.030

Valkama, E., Lemola, R., Känkänen, H., and Turtola, E. (2015). Meta-analysis of the effects of undersown catch crops on nitrogen leaching loss and grain yields in the Nordic countries. Agric. Ecosyst. Environ. 203, 93-101. doi: 10.1016/j.agee.2015.01.023

Valle, O. (1951). Über die Anbaumöglichkeiten von Winterrübsen in Finnland. Forsk. Forsøk Landbr. 2, 38-51.

van Ruijven, J., and Berendse, F. (2003). Positive effects of plant species diversity on productivity in the absence of legumes. Ecol. Lett. 6, 170-175. doi: 10.1046/j.1461-0248.2003.00427.x

Vandermeer, J. (1981). The interference production principle: an ecological theory for agriculture. BioScience 31, 361-364. doi: 10.2307/1308400

Vandermeer, J. (1989). The Ecology of Intercropping. Cambridge: Cambridge University Press. doi: 10.1017/CBO9780511623523

Vico, G., Hurry, V., and Weih, M. (2014). Snowed in for survival: quantifying the risk of winter damage to overwintering field crops in northern temperate latitudes. Agric. For. Meteor. 197, 65-75. doi: 10.1016/j.agrformet.2014. 06.003

Virkajärvi, P., Pakarinen, K., Hyrkäs, M., Seppänen, M. M., and Bélanger, G. (2012). Tiller characteristics of timothy and tall fescue in relation to herbage mass accumulation. Crop Sci. 52, 970-980. doi: 10.2135/cropsci2011. 01.0039 
Vogeler, I., Hansen, E. M., Thomsen, I. K., and Østergaard, H.S. (2019). Legumes in catch crop mixtures: effects on nitrogen retention and availability, and leaching losses. J. Environ. Manage. 239, 324-332. doi: 10.1016/j.jenvman.2019.03.077

Wahlström, E. M., Møller Hansen, E., Mandel, A., Garbout, A., Lakkenborg Kristensen, H., and Munkholm, L. J. (2015). Root development of fodder radish and winter wheat before winter in relation to uptake of nitrogen. Eur. J. Agron. 71, 1-9. doi: 10.1016/j.eja.2015.07.002

Yang, X. M., Drury, C. F., Reynolds, W. D., and Reeb, M. D. (2019). Legume cover crops provide nitrogen to corn during a three-year transition to organic cropping. Agron. J. 111, 3253-3264. doi: 10.2134/agronj2018.10.0652

Zhao, J., De Notaris, C., and Olesen, J. E. (2020). Autumn-based vegetation indices for estimating nitrate leaching during autumn and winter in arable cropping systems. Agric. Ecosyst. Environ. 290:106786. doi: 10.1016/j.agee.2019.1 06786
Zimdahl, R. L. (2004). Weed - Crop Competition. Iowa: Blackwell Publishing. doi: 10.1002/9780470290224

Conflict of Interest: The authors declare that the research was conducted in the absence of any commercial or financial relationships that could be construed as a potential conflict of interest.

Copyright (C) 2020 Lizarazo, Tuulos, Jokela and Mäkelä. This is an open-access article distributed under the terms of the Creative Commons Attribution License (CC BY).

The use, distribution or reproduction in other forums is permitted, provided the original author(s) and the copyright owner(s) are credited and that the original publication in this journal is cited, in accordance with accepted academic practice. No use, distribution or reproduction is permitted which does not comply with these terms. 